\title{
PENERAPAN UNDANG-UNDANG NOMOR 14 TAHUN 2008 \\ TENTANG KETERBUKAAN INFORMASI PUBLIK (STUDI DI PEMERINTAHAN KABUPATEN INDRAGIRI HILIR)
}

\author{
Oleh : Ihsan Fahlevi \\ Dosen Pembimbing : 1. Jamri SH,.MH, 2. KMS. Novyar Satriawan SH,.MH
}

\begin{abstract}
ABSTRAK
Memperoleh informasi publik merupakan hak asasi manusia. Jaminan keterbukaaan informasi publik adalah ciri penting bagi sebuah negara yang demokratis. Keterbukaan informasi publik merupakan wujud nyata pengawasan publik/masyarakat terhadap penyelenggaraan negara dan segala sesuatu yang berakibat pada kepentingan publik. Keterbukaan informasi merupakan sebuah acuan dalam upaya mewujudkan akuntabilitas publik para penyelengggaraan negara. Hal ini telah sesuai dengan prinsip-prinsip good governance. Dengan dibentuknya Undang-Undang Nomor 14 Tahun 2008 tentang Keterbukaan Informasi Publik semakin melegitimasi masyarakat akan hak-hak mereka untuk mendapatkan informasi, serta merupakan angin segar bagi masyarakat yang menginginkan transparansi di segala sektor apalagi yang menyangkut sektor publik, namun hal ini tidak terjadi di Kabupaten Indragiri Hilir, permintaan informasi oleh masyarakat umum hampir tidak dilayani oleh instansi terkait dengan alasan takut disalah gunakan. Hal ini tentu saja dapat memicu masalah akibat tidak adanya keterbukaan informasi publik.

Dari uraian latar belakang tersebut, penulis merumuskan masalah yaitu (1) Bagaimana pelaksanaan keterbukaan informasi mengenai Peraturan Daerah Kabupaten Indragiri Hilir (2) Apa penghambatan pelaksanaan keterbukaan informasi mengenai Peraturan Daerah Kabupaten Indragiri Hilir (3) Apa upaya mengatasi hambatan pelaksanaan Keterbukaan Informasi mengenai Peraturan Daerah Kabupaten Indragiri Hilir

Penelitian ini merupakan penelitian empiris/sosiologis menitikberatkan pada penelitian langsung/lapangan. Sumber data yang digunakan adalah data primer yaitu data utama yang diperoleh oleh peneliti melalui responden atau sampel. Data sekunder yaitu data yang diperoleh dari buku-buku literature yang mendukung dengan pokok masalah yang dibahas. Sedangkan sifat penelitian yang penulis gunakan adalah penelitian Deskriftif. Analisis data dilakukan dengan observasi dan penarikan kesimpulan dilakukan dari umum ke khusus (deduktif).

Berdasarkan hasil penelitian dan pembahasan bahwa, pertama dalam pelaksanaan keterbukaan informasi mengenai Peraturan Daerah Kabupaten Indragiri Hilir yaitu daerah Pelaksanaan keterbukaan informasi di Kabupaten Indragiri Hilir ini belum sepenuhnya berjalan dengan maksimal, masih ada sebagian masyarakat yang mengeluh tentang susahnya mengakses informasi yang mereka inginkan. Jika pemohon menginginkan informasi tentang peraturan daerah, dilihat peraturan daerah apa yang diinginkan. Kedua faktor penghambatan pelaksanaan keterbukaan informasi mengenai Peraturan Daerah Kabupaten Indragiri Hilir yaitu Keterbatasan media elektronik sebagai sarana informasi yang disampaikan kepada masyarakat seperti beberapa kecamatan belum bisa mengakses jaringan internet, belum ada SOP mengatur tentang keterbukaan informasi publik ini dan ketiga upaya mengatasi hambatan pelaksanaan Keterbukaan Informasi mengenai Peraturan Daerah Kabupaten Indragiri Hilir yaitu Pemerintah Kabupaten Indragiri Hilir sudah menyediakan media senter untuk masyarakat agar bisa mengakses informasi yang diinginkan, strukturnya juga sudah ada, gedungnya juga sudah ada, gedung media centernya terletak di sebelah gedung GTV dan semua kalangan bisa nantinya mendapatkan informasi yang diinginkan melalui media center tersebut.
\end{abstract}




\section{DAFTAR PUSTAKA}

a) Buku-buku

Ali Achmad. 2001. Menguak tabir Hukum ( Satu Kajian Filosofis dan Sosiologis). PT. Tokoh Gunung Agung Tbk, Jakarta.

Drs.Sudarsono.S.H.M.SI,2007.Pengantar Ilmu hukum.Cetakan ke 5.PT Rineka Cipta, jakarta.

Warassih Esmi, 2005. Pengantar Sosiologis. PT Raja Grafindo Persada, Jakarta.

Warassih Esmi, 2005.Pranata Hukum: Sebuah Telaah sosialogi.PT Suryandaru Utama, Semarang

Kusnardi.S.H Moh dan Prof.Dr.Bintan R.Saragih.MA,1993. Ilmu Negara.Pt.Gaya Media

Pratama,Jakarta

Farida Indrati S Maria, 2007. Ilmu Perundang-Undangan 1: Jenis, fungsi dan Materi Muatan.

Cetakan Ke-8. Kanisius (Anggota IKAPI), Yogyakarta

Rahimullah. 2007, Hukum Tata Negara: Ilmu Perundang-Undangan. PT Gramedia, Jakarta.

Ridwan HR,2006.Hukum Administrasi Negara.PT RajawaliGrafindo.Jakarta

Soeroso R, 2004. Pengantar Ilmu Hukum. Sinar Grafika, Jakarta.

Rahardjo Satjipto. 1997. Sosiologi Hukum : Perkembangan, Metode dan Pilihan Masalah, Cetakan 1. Muhammadiyah University Press, Surakarta..2002. Ilmu Hukum. PT.CitraAditya

Rahardjo Satjipto,2002,Ilmu Hukum.PT.CitraAditya,Bandung.

Sugiyono,2010,Metode Penelitian,Alfabel,Bandung.

b) Peraturan Perundang-undangan

Undang-undang No.32 tahun 2004. Tentang Pemerintahan Daerah

Undang-undang No 10 Tahun 2004 Tentang Pembentukan Peraturan perundang undanagan

Undang-undang No 33 Tahun 2004 Tentang Perimbangan Keuangan

Undang-undang Nomor 25 Tahun 2010 Tentang Retribusi Izin Usaha Perikanan

Undang-undang No 5 Tahun 1986 Tentang peradilan tata usaha negara

c) Internet

pada tanggal 16-12-2015.hari rabu.pukul

10:00https://masguruonline.wordpress.com/2013/09/25/lembaga-pemerintahan-kabupaten-kotadan-provinsi 


\section{d)Hasil Interview (Wawancara)}

Hasil Wawancara dengan pelaku usaha budidaya ikan air tawar di kecamatan tembilahan pada tanggal 22 september 2015

Hasil Wawancara dengan salah satu anggota Dinas perikanan dan kelautan dikecamatan tembilahan 29 september 2015

Hasil wawancara dengan salah satu anggota satpol pp dikecamatan tembilahan pada tanggal 5 januari 2016

e) Jurnal

Ali Azhar, KMS Novyar Satriawan Fikri. 2020. Study Of Law Number 9 Off Regarding Freedom Of Speech In Publice, International Journal of Scientific \& Technology Research 9(1) : 4002-4006

Mulono Apriyanto, KMS. Novyar Satriawan Fikri, Vivi Arfiani Siregar, Jamri, Ali Azhar. 2020. Penyuluhan Tentang Peremajaan Kelapa Sawit Dan Legalitas Lahan Di Kecamatan Kempas Kabupaten Indragiri Hilir, JPM: Jurnal Pengabdian Masyarakat 1(1) : 1-16

KMS Novyar Satriawan Fikri, Ali Azhar. 2020. Academic Study Of District Formation South Indragiri. Progressive law review 2 (1) : 1-13

KMS Novyar Satriawan Fikri, Ali Azhar. 2020, Implementation of Discipline Policy for Civil Servants in Indragiri Hilir Regency Post Covid Pandemic 19, Proceedings of the 5th NA International Conference on Industrial Engineering and Operations Management.

Mulono Apriyanto, KMS Novyar Sariawan Fikri, Ali Azhar, 2020. Pendampingan Santri untuk Penurunan Tingkat Pelanggaran Lalu Lintas 1 (2) : 238-247.

KMS Novyar Satriawan Fikri, Herdiansyah, 2019. To Fighting The Covid 19 Virus In Indragiri Hilir. Jurnal Hukum DAS SOLLEN3 (2) : 23-45

KMS Novyar Satriawan Fikri, Fauziah Rahmah. 2018. Pelaksanaan Pemekaran Kecamatan Sentajo Raya Kabupaten Kuantan Singingi Menurut Peraturan Pemerintah Nomor 19 Tahun 2008 Tentang Kecamatan (Studi Terhadap Pasal 4 Huruf C dan D). Jurnal Hukum DAS SOLLEN 1 (4) : 1-10 